\title{
Kemampuan Bakteri Asam Laktat Dalam Menghambat Pertumbuhan dan Produksi Aflatoksin $B_{2}$ Aspergilllus flavus
}

\author{
Arina Tri Lunggani \\ Laboratorium Mikrobiologi, Jurusan Biologi FMIPA Undip
}

\begin{abstract}
Aflatoxins are highly toxic secondary metabolies produced during the growth of several fungi, especially Aspergillus flavus. $A F B_{1}$ and $A F B_{2}$ one of them which contaminates a wide variety of food and feed causing serious health problem when consumed by human or animals. This research was aimed to study the potency of Lactic Acid Bacteria $(L A B)$ in the inhibition of Aspergillus flavus growth and the production of Aflatoxin $B_{2}$. Three species of LAB i.e. Lactobacillus delbrueckii, L. fermentum, L. plantarum were investigated for their potential in inhibiting and degradation of Aflatoxin $B_{2}$ as well as inhibiting fungal growth. The trial was designed into three variations of each isolate by challenging the fungal culture, before fungal inoculation, at the same time as fungal inoculation and after fungal inoculation. It was found that all the three species of LAB are potential microorganism to inhibit fungal growth as indicated by the reduction of the dry weight of fungal mycelia compared with control. Quantification of Aflatoxin $B_{2}$ showed that L. fermentum gave the strongest degradation of Aflatoxin $B_{1}$ during 15 days incubation, then followed by L. plantarum and L delbruekii with a reduction rate of 0,,2408 ppm, 0,3373 ppm, 0,6393 ppm respectively, compared with control these are significantly different. These result conclude that Aflatoxin $B_{2}$ can be degraded or prevented to be produced by A. flavus by applying $L A B$.
\end{abstract}

Key words : Aflatoksin, Aspergillus flavus

\section{PENDAHULUAN}

Aflatoksin adalah suatu metabolit sekunder yang terbentuk setelah fase logaritmik pertumbuhan kapang Aspergillus flavus dan A. parasiticus (Mehan et al, 1991). Indonesia yang beriklim tropis, kontaminasi aflatoksin sering ditemukan pada produk-produk pertanian dan hasil olahan. Selain itu, residu aflatoksin dan metabolitnya juga ditemukan pada produk-produk peternakan seperti susu, telur dan daging ayam (Oatley et al,2000, Maryam, 1996 )

Aflatoksin merupakan salah satu jenis mikotoksin yang bersifat toksigenik, mutagenik, teratogenik, dan karsinogenik (Makfoeld, 1993). Aflatoksin terdiri dari 4 komponen induk yaitu, aflatoksin $\mathrm{B}_{1}$ $\left(\mathrm{AFB}_{1}\right)$, aflatoksin $\mathrm{B}_{2}\left(\mathrm{AFB}_{2}\right)$, aflatoksin $\mathrm{G}_{1}$ $\left(\mathrm{AFG}_{1}\right)$ dan aflatoksin $\mathrm{G}_{2}\left(\mathrm{AFG}_{2}\right)$. Di antara keempat jenis aflatoksin ini, diketahui aflatoksin $\mathrm{B}_{1}\left(\mathrm{AFB}_{1}\right)$ dan aflatoksin $\mathrm{B}_{2}\left(\mathrm{AFB}_{2}\right)$ termasuk yang berbahaya.,sehingga pengembangan penelitian banyak difokuskan pada aflatoksin jenis ini. (Coallier \& Idzack, 1985; Makfoeld, 1993).
Resiko kesehatan yang ditimbulkan jika konsumen mengkonsumsi produk yang telah terkontaminasi A. flavus dan aflatoksin ini sangat besar, sedangkan proses pengolahan makanan tradisional belum dapat menghilangkan cemaran aflatoksin sampai batas aman. Oleh karena itu perlu diupayakan suatu metode kombinasi secara biologis, dengan terus melakukan eksplorasi dan skrining mikroba kompetitor yang memenuhi standar "food grade " dan mampu menurunkan kadar aflatoksin (Bata \& Lasztity, 1999; Nezami et al, 2000).

Kelompok bakteri asam laktat (BAL) merupakan mikroba yang diharapkan mampu untuk dijadikan sebagai alternatif solusi masalah kontaminasi A. flavus termasuk produksi aflatoksinnya. Lactobacillus rhamnosus dan Propionobacterium yang termasuk bakteri asam laktat diketahui mampu mendegradasi aflatoksin $\mathrm{B}_{1}$ dan aflatoksin $\mathrm{B}_{2}$ dari usus ayam (Nezami et al, 2000). Penelitian ini bertujuan untuk mengetahui kemampuan kelompok bakteri asam laktat (Lactobacillus delbrueckii, L. fermentum dan L. 
plantarum) dalam menghambat pertumbuhan dan produksi $\mathrm{AFB}_{2}$ dari Aspergillus flavus.

\section{BAHAN DAN METODE}

Bahan yang digunakan dalam penelitian ini ber Bahan upa kultur murni Aspergillus flavus dan bakteri asam laktat (Lactobacillus delbruekii, $L$. fermentum dan $L$. plantarum) yang diperoleh dari Laboratorium Mikrobiologi UGM, Yogyakarta. Ketiga bakteri laktat tersebut ditumbuhkan pada medium LTA ("Lablemco Tripton Agar") dan LTB. Ketiga bakteri laktat yang digunakan dalam penelitian diaktivasi lebih dulu. ini adalah :

Metoda yang digunakan dalam penelitian

a. Pembuatan kurva tumbuh Lactobacillus delbruekii, L. fermentum dan L.plantarum

b. Esei mikrobiologi BAL dalam menghambat pertumbuhan A. flavus dan aflatoksin $\mathrm{B}_{2}$ (Coolier \& Idzack, 1985). Metode ini pada prinsipnya menumbuhkan kedua jenis mikroba tersebut di dalam satu medium kemudian diinkubasikan selama 15 hari dengan fermentasi permukaan (kultur statis). Setelah waktu inkubasi yang telah ditentukan tercapai, dilakukan pengukuran pertumbuhan A. flavus dan produksi Aflatoksin $\mathrm{B}_{2}$ oleh A. flavus

c. Ekstraksi Aflatoksin $\mathrm{B}_{2}$ (Coolier \& Idzack, 1985).

d. Analisis Aflatoksin $\mathrm{B}_{2}$ secara kualititatif (Coolier \& Idzack, 1985).

Analisis aflatoksin secara kualitatif dilakukan dengan metode Kromatografi Lapis Tipis (KLT) dengan membandingkan $\mathrm{Rf}$ standar aflatoksin dengan Rf sampel.

e. Analisis Aflatoksin $\mathrm{B}_{2}$ secara kuantitatif (Coolier \& Idzack, 1985).

Analisis kuantitatif untuk mengukur kadar aflatoksin dilakukan dengan metode secara langsung yaitu dengan melewatkan pelat kromatogram pada Camag TLC Scanner II yang dilengkapi dengan komputer untuk analisisnya (IBM model 50 dengan CATS Software). Hasil pengukuran akan menunjukkan garis integrasi yang sebanding dengan kadar aflatoksin yang diukur.
Penelitian dilakukan dengan membuat 2 variasi perlakuan:

1. Waktu pemberian inokulum BAL pada medium LTC :

$\mathrm{A}_{1}$ : A. flavus ditumbuhkan lebih dulu pada medium sebelum dicampur dengan kultur BAL.

$\mathrm{A}_{2}$ : $\mathrm{BAL}$ ditumbuhkan lebih dulu pada medium sebelum dicampur dengan spora $A$. flavus ; $\mathrm{A}_{3}$ : $\mathrm{BAL}$ dan spora kapang $A$. flavus ditumbuhkan pada waktu yang bersamaan pada medium pertumbuhan

2. Jenis BAL yang digunakan :

$\mathrm{L}_{1}:$ L. delbruekii $: \mathrm{L}_{2}:$ L. fermentum $: \mathrm{L}_{3}$ : L. plantarum

3. Jadi kombinasi perlakuan yang dilakukan adalah :

$\mathrm{A}_{1} \mathrm{~L}_{1}, \mathrm{~A}_{1} \mathrm{~L}_{2}, \mathrm{~A}_{1} \mathrm{~L}_{3}$

$\mathrm{A}_{2} \mathrm{~L}_{1}, \mathrm{~A}_{2} \mathrm{~L}_{2}, \mathrm{~A}_{2} \mathrm{~L}_{3}$

$\mathrm{A}_{3} \mathrm{~L}_{1}, \mathrm{~A}_{3} \mathrm{~L}_{2}, \mathrm{~A}_{3} \mathrm{~L}_{3}$

Sebagai Kontrol adalah pengukuran pertumbuhan A. flavus dan produksi Aflatoksin $\mathrm{B}_{2}$ pada medium LTC tanpa penambahan kultur BAL

\section{HASIL DAN PEMBAHASAN}

1. Pengaruh Bakteri asam laktat terhadap pertumbuhan Aspergillus flavus.

Berdasarkan hasil penelitian diketahui walaupun di dalam medium pertumbuhannya terdapat mikroba lain, yaitu bakteri asam laktat yang dapat bersifat sebagai kompetitor dan juga perubahan konsentrasi substrat yang terlarut di dalam medium, A. flavus masih mampu untuk tetap "survive" (bertahan hidup) yang dibuktikan dengan adanya pertambahan biomasa selama 15 hari waktu inkubasi, meskipun jumlahnya mengalami reduksi dibandingkan kontrol. Berdasarkan data tersebut dapat diketahui pula bahwa masing-masing spesies bakteri asam laktat mempunyai kemampuan yang berbeda dalam menekan pertumbuhan A. flavus. Species yang berbeda ini pada dasarnya mempunyai pola metabolisme yang berbeda pula. L. delbruekii dan $L$ plantarum yang tergolong bakteri asam laktat homofermentatif melakukan jalur katabolisme glukosa melalui jalur Embden Meyerhoff Parnas (EMP) atau disebut juga dengan glikolisis. $L$. 
fermentum yang tergolong bakteri asam laktat heterofermentatif tidak memiliki enzim utama jalur glikolisis yaitu aldolase, untuk melakukan katabolisme glukosa melalui jalur fosfoketolase (Fardiaz, 1988; Lehniger, 1994).

Walaupun diinokulasikan ke dalam medium yang telah berisi mikroba lain, Lactobacillus mempunyai respon yang cukup baik dalam menghadapi stress lingkungan yang sedikit banyak mempengaruhi proses metabolismenya. Kemampuan Lactobacillus untuk mampu beradaptasi bahkan mampu juga menekan pertumbuhan A. flavus, kemungkinan disebabkan pada saat diinokulasikan ke dalam medium LTB, A. flavus baru berada pada fase pertumbuhan awal sehingga enzim-enzim yang terlibat pada proses pertumbuhan belum pada kondisi yang optimal, sebaliknya Lactobacillus berada pada fase exponensial dimana enzim-enzim yang terlibat berada kondisi yang optimal. Residu glukosa yang tersedia di dalam medium kemudian secara cepat dimanfaatkan oleh Lactobacillus untuk menjalankan proses metabolisme.

Interaksi pertumbuhan antara ketiga spesies bakteri asam laktat dengan waktu inokulasi yang berlainan memberikan pola yang sama terhadap pertumbuhan A. flavus yaitu terjadi penekanan dalam kemampuan $A$. flavus dalam membentuk biomasa yang ditunjukkan dengan jumlah biomasa $A$. flavus yang lebih rendah dibandingkan kontrol. Jika dibuat suatu rangkuman dalam bentuk tabulasi banyaknya biomasa A. flavus yang dihasilkan pada ketiga perlakuan pada hari ke 15 maka hasilnya dapat diamati pada tabel.1.Berdasarkan tabel tersebut terlihat bahwa dari ketiga jenis bakteri asam laktat yang digunakan dalam penelitian ini mempunyai kemampuan yang berbeda dalam menekan kemampuan A. flavus dalam membentuk biomasa meskipun secara statistik tidak signifikan.

Tabel 1. Biomasa A. flavus pada ketiga perlakuan selama 15 hari dalam medium LTB pada temperatur ruang.

Reduksi berat kering A. flavus pada perlakuan dapat disebabkan oleh beberapa hal, diantaranya adalah :

Faktor lingkungan yang berpengaruh dalam proses interaksi antara bakteri asam laktat dan A. flavus ini diantaranya adalah $\mathrm{pH}$.
Perubahan $\mathrm{pH}$ merupakan suatu fungsi dari ketersediaan nutrisi dan metabolit yang dihasilkan selama pertumbuhan yang terdapat dalam medium. Bakteri asam laktat merupakan mikroba yang mempunyai kemampuan dalam menciptakan respon terhadap keasaman medium.

Reduksi berat kering A. flavus pada perlakuan dapat disebabkan oleh beberapa hal , diantaranya adalah :

Faktor lingkungan yang berpengaruh dalam proses interaksi antara bakteri asam laktat dan A. flavus ini diantaranya adalah $\mathrm{pH}$. Perubahan $\mathrm{pH}$ merupakan suatu fungsi dari ketersediaan nutrisi dan metabolit yang dihasilkan selama pertumbuhan yang terdapat dalam medium. Bakteri asam laktat merupakan mikroba yang mempunyai kemampuan dalam menciptakan respon terhadap keasaman medium.

\begin{tabular}{|c|c|c|c|c|}
\hline \multirow[t]{2}{*}{$\begin{array}{l}\text { Jenis Bakteri } \\
\text { Asam Laktat }\end{array}$} & \multicolumn{4}{|c|}{$\begin{array}{c}\text { Biomasa } A \text {. flavus pada } \\
\text { hari ke } 15(\mathrm{~g})\end{array}$} \\
\hline & A1 & A2 & A3 & $\begin{array}{c}\text { Rata- } \\
\text { rata }\end{array}$ \\
\hline L. delbrueckii & 0.4986 & 0.5247 & 0.5400 & $0.5211 * *$ \\
\hline L. fermentum & 0.4196 & 0.5024 & 0.4196 & $0.4472 * *$ \\
\hline L. plantarum & 0.3989 & 0.3254 & 0.3254 & $0.3499 * *$ \\
\hline Kontrol & & & & 0.6234 \\
\hline
\end{tabular}

\section{Keterangan :}

A1: Perlakuan A. flavus ditumbuhkan terlebih dahulu pada medium LTB sebelum diinokulasi dengan bakteri asam laktat.

A2 : Perlakuan bakteri asam laktat ditumbuhkan terlebih dahulu pada medium LTB sebelum diinokulasi dengan A. flavus.

A.3 : Perlakuan inokulasi bakteri asam laktat dan A. flavus dilakukan secara bersamaan.

** : Berbeda sangat nyata pada selang kepercayaan $95 \%$.

Dinamika nilai $\mathrm{pH}$ mempengaruhi pertumbuhan kedua jenis mikroba tersebut. $A$. flavus sebenarnya mempunyai kisaran $\mathrm{pH}$ yang cukup rendah untuk pertumbuhannya sehingga sebenarnya rendahnya $\mathrm{pH}$ tidak berpengaruh secara signifikan, namun interaksinya dengan bakteri asam laktat lebih ditekankan karena bakteri asam laktat tersebut mempunyai kemampuan untuk bereaksi lebih cepat untuk menghadapi 
stress asam sehingga aktivitas metabolismenya tidak terganggu. Sebaliknya bagi A. flavus membutuhkan energi yang relatif lebih banyak untuk merespon lingkungannya yang asam disamping untuk proses metabolismenya (Ray,1992; Fardiaz,1992). Hal ini mengakibatkan pertumbuhannya kurang optimal sehingga jumlah biomasa yang dihasilkan menjadi lebih rendah dibanding kontrol

Adanya komponen penghambat tertentu yang dihasilkan oleh bakteri asam laktat ( Coallier dan Idzack, 1985 ). Betty ( 1999) menyatakan bahwa komponen penghambat yang dihasilkan oleh Bakteri asam laktat umumnya bersifat tahan panas. Mekanisme penghambatan komponen antimikroba ini terhadap mikroba target adalah dengan cara destabilisasi dari membran sitoplasma.

Bakteri asam laktat, baik yang bersifat homofermentatif maupun heterofermentatif memanfaatkan substrat yang tersedia pada lingkungannya dengan hasil akhir berupa energi dan asam-asam lemah seperti asam laktat, asam asetat serta $\mathrm{CO}_{2}$. Keberadaan asam laktat sebagai produk metabolisme dapat bersifat sebagai salah satu faktor penghambat bagi pertumbuhan $A$. flavus. Jumlah asam laktat yang berpengaruh terhadap pertumbuhan jamur berkisar antara 0.75 $\%$ - 1,5\% (Gourama dan Bullerman, 1995 ).

Mekanisme antimikroba asam laktat berdasarkan teori " chemiosmotic " dan pH homeostasis. Ketika asam laktat yang diproduksi disekresikan ke lingkungan, beberapa molekul terdissosiasi menjadi $\mathrm{H}^{+}$dan anion, sementara yang lain tidak terdissosiasi. Salah satu faktor yang berperanan terhadap terdissosiasi atau tidaknya suatu molekul adalah pH lingkungan dan pK (tetapan keseimbangan). Hal ini menyebabkan peningkatan proton transmembran yang pada akhirnya menyebabkan gradient proton. Perbedaan ini menyebabkan proton lebih cepat masuk ke dalam sel sehingga meningkatkan kebutuhan energi untuk mempertahankan $\mathrm{pH}$ alkali dalam sel. (Ray, 1992). Namun hal yang kontradiktif dinyatakan oleh Coallier \& Idzack (1995) yang menyatakan bahwa asam laktat tidak bersifat sebagai penghambat dalam pertumbuhan A. flavus termasuk juga produksi aflatoksinnya. Asam laktat ini justru sebagai faktor pendukung bagi pertumbuhan A. flavus dan dapat bersifat sebagai kofaktor dalam pembentukan aflatoksin. Mekanisme ini didasarkan teori bahwa pada suatu substrat yang mempunyai konsentrasi asam laktat yang berlebih maka sel akan berusaha untuk mengoksidasi kembali asam laktat tersebut menjadi piruvat sebagai salah satu alternatif untuk mendapatkan energi dan mekanisme proteksi pada lingkungan yang ekstrim (Moat \& Foster, 1995). Dari hasil penelitian dapat diamati bahwa terjadi pertambahan biomasa pada 15 hari waktu inkubasi . Hasil ini sesuai dengan pernyataan Coallier \& Idzack (1995) bahwa kemungkinan asam laktat yang dihasilkan oleh bakteri asam laktat ini mampu dimanfaatkan oleh A. flavus untuk mendukung pertumbuhannya.

Interaksi antara bakteri asam laktat dan $A$. flavus terjadi dalam suatu sistim fermentasi statis dimana tidak dilakukan penambahan komponen substrat setelah inokulasi ke dalam medium tersebut selama proses fermentasi berlangsung. Hal ini mengakibatkan aktivitas metabolisme mikroba yang terlibat di dalamnya terjadi secara simultan. Berdasarkan kecepatan aktivitas metabolismenya bakteri mempunyai kecenderungan untuk menjalankan proses katabolisme lebih cepat dibandingkan jamur. Hal ini menyebabkan perubahan kondisi medium. Menurut Slater (1981), suatu komunitas terbentuk jika kondisi lingkungan mengakibatkan pertumbuhan lebih dari satu populasi mikroba dan pada waktu dan kondisi tertentu masing-masing anggota populasi saling berinteraksi. Jadi pada dasarnya proses interaksi itu tidak selalu terjadi selamanya namun hanya pada suatu periode tertentu namun akibat dari proses interaksi tersebut dapat berpengaruh terhadap mikroba yang terlibat di dalamnya.

\section{PENGARUH BAKTERI ASAM LAKTAT TERHADAP PENURUNAN KADAR AFLATOKSIN B . $_{2}$.}

Interaksi pertumbuhan antara ketiga jenis bakteri asam laktat dengan waktu inokulasi yang berlainan memberikan pola yang sama terhadap penurunan kemampuan A. flavus dalam memproduksi aflatoksin $B_{2}$. Jika dibuat suatu rangkuman dalam bentuk tabulasi, jumlah aflatoksin $B_{2}$ yang dihasilkan pada ketiga 
perlakuan pada hari ke 15 maka hasilnya dapat diamati pada tabel 2. Tabel tersebut memperlihatkan bahwa dari ketiga jenis bakteri asam laktat yang digunakan dalam penelitian ini mempunyai kemampuan yang berbeda dalam mereduksi kadar $\mathrm{AFB}_{2}$ dalam medium uji.

Tabel 2. Rangkuman jumlah aflatoksin $B_{2}$ yang dihasilkan pada ketiga perlakuan pada hari ke 15 dalam medium LTB pada temperatur ruang.

\begin{tabular}{lcccc}
\hline Jenis Bakteri & \multicolumn{4}{c}{ Kadar aflatoksin $\mathbf{B}_{2}$ pada } \\
Asam Laktat & \multicolumn{4}{c}{$\mathbf{A 3}$ hari 15 $(\mathbf{p p m})$} \\
\cline { 2 - 5 } & $\mathbf{A 1}$ & $\mathbf{A 2}$ & $\mathbf{A 3}$ & $\begin{array}{c}\text { Rata- } \\
\text { rata }\end{array}$ \\
\hline L. delbrueckii & 0,652 & 0,831 & 0,435 & $0,6393^{* *}$ \\
L. fermentum & 0,076 & 0,412 & 0,234 & $\mathbf{0 , 2 4 0 8 ^ { * * }}$ \\
$\begin{array}{l}\text { L. plantarum } \\
\text { Kontrol }\end{array}$ & 0,752 & 0,138 & 0,122 & $0,3373^{* *}$ \\
\hline
\end{tabular}

Keterangan :

A1. : Perlakuan A. flavus ditumbuhkan terlebih dahulu pada medium LTB sebelum diinokulasi dengan bakteri asam laktat.

A2 : Perlakuan bakteri asam laktat ditumbuhkan terlebih dahulu pada medium LTB sebelum diinokulasi dengan $A$. flavus.

A.3 : Perlakuan inokulasi bakteri asam laktat dan A. flavus dilakukan secara bersamaan.

** : Berbeda sangat nyata pada selang kepercayaan $95 \%$.

Mekanisme sintesis aflatoksin $\mathrm{B}_{2}$ dapat dijelaskan melalui gambar berikut Eaton,and Groopman. 1994 :

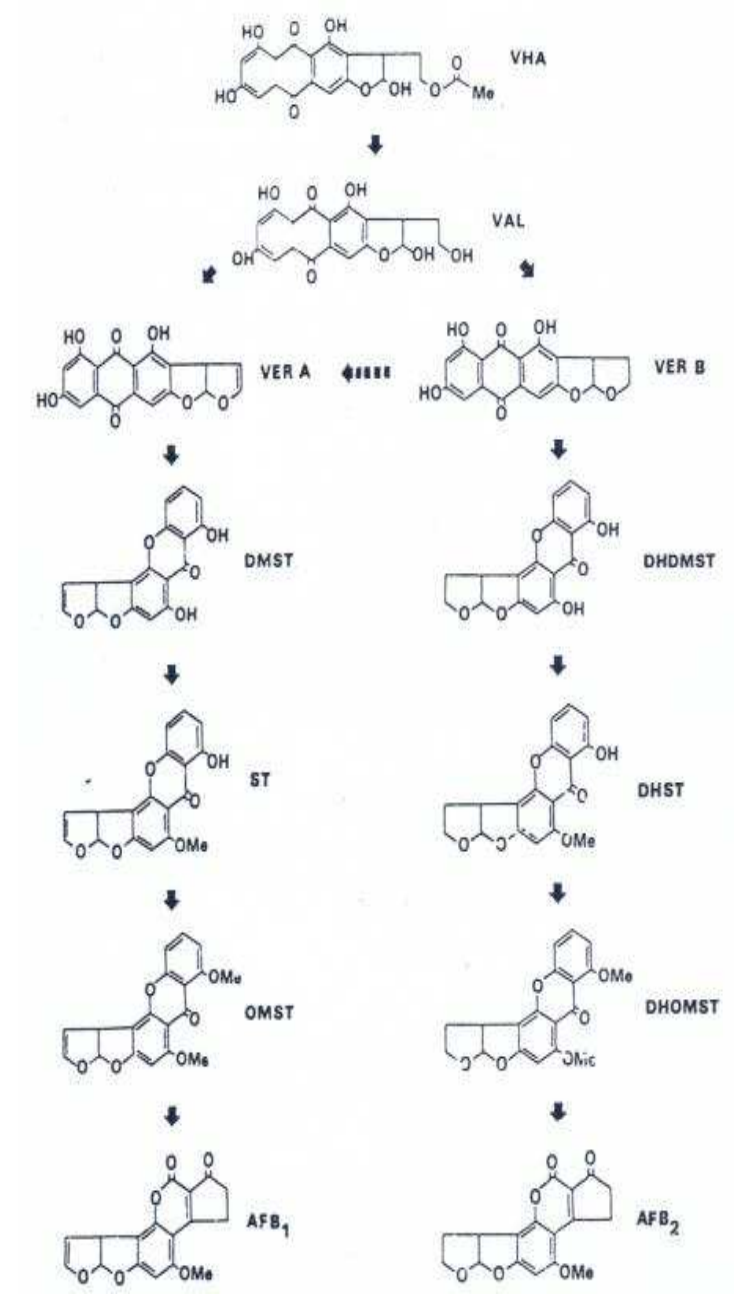

Setidaknya ada 20 reaksi enzimatik yang dibutuhkan oleh A. flavus untuk memproduksi $\mathrm{AFB}_{2}$ (Chang et al, 2007:, Chiou et al, 2002 ). Gen yang bertanggung jawab terhadap produksi Aflatoksin $\mathrm{B}_{2}$ disebut sebagai gen Afl $\mathbf{J}$ dan gen Afl B (Meyers et al, 1998 ). Kegagalan ekspresi gen dapat terjadi jika gen penyandi aflatoksin $\mathrm{B}_{2}$ rusak atau dalam waktu pengamatan 15 hari tersebut, kecepatan pembentukan Aflatoksin $\mathrm{B}_{2}$ menjadi berkurang akibat cekaman pada substrat pertumbuhannya akibat akumulasi produk metabolit dari bakteri asam laktat (Chiou et al, 2002).

Metabolit yang bersifat asam baik yang dihasilkan oleh Bakteri asam laktat maupun $A$. flavus selama fase logaritmik akhir bersifat akumulatif didalam medium. Kondisi ini 
membuat pertumbuhan kedua jenis mikroba menjadi kurang optimal. Menurut Haskard et al (2001) asam yang terlalu tinggi akan memacu terjadinya lubang pada dinding sel. Walaupun lapisan peptidoglikan pada bakteri gram positif ini cukup tebal, namun peristiwa pemutusan ikatan oleh asam ini akan menurunkan ketebalan, melonggarkan ikatan silang antar komponen dan pada akhirnya akan memperbesar ukuran lubang. Kondisi yang terjadi pada dinding sel memungkinkan $\mathrm{AFB}_{2}$ untuk terikat pada dinding sel dan plasma membran dengan suatu mekanisme pengikatan tertentu ( Haskard et al, 2001 ).

Interaksi mikroba merupakan suatu sistem yang dinamis, yaitu terjadi perubahan yang terus menerus pada populasi mikroba yang terlibat di dalamnya. Adanya kompetisi untuk mendapatkan nutrisi yang terbatas, kondisi lingkungan yang kurang mendukung, akumulasi metabolit yang kemungkinan beracun akan menginduksi enzimenzim tertentu untuk bereaksi agar proses metabolisme dapat terus berlangsung. Bakteri asam laktat kemungkinan mempunyai kemampuan untuk menurunkan kadar Aflatoksin $\mathrm{B}_{2}$ yang terbentuk dengan suatu mekanisme enzimatik tertentu, walaupun untuk membuktikan hal ini perlu dilakukan penelitian lebih lanjut.

Rendahnya kadar Aflatoksin $\mathrm{B}_{2}$ dibanding kontrol kemungkinan disebabkan karena A. flavus tidak mampu memproduksi Aflatoksin $\mathrm{B}_{2}$ secara optimal. Pada interaksi ini biomasa A. flavus yang terbentuk pada perlakuan secara kwantitas lebih rendah dibandingkan kontrol, sehingga hal ini akan berkorelasi langsung terhadap kemampuan $A$. flavus dalam memproduksi Aflatoksin $\mathrm{B}_{2}$

\section{DAFTAR PUSTAKA}

Adnan, M., 1997. Teknik Kromatografi Untuk Analisis Bahan Makanan. Andi Offset. Yogyakarta. P. $9-25$

Bata, A \& Lasztity, R. 1999. Detoxification of Mycotoxin Contaminated Food and Feed by microorganism. Trends in Food Science and Technology $10: 223$ - 228.

Chiou, C.H., Miller, M., Wilson D.L, Trail, F dan Linz, J. E. 2002. Chromosomal Location Plays a role in regultion of Aflatoxin gene expression in Aspergillus parasiticus. Applied and Enviromental Microbiology (abstrak) Vol 68 (1): 306 -315

Chang, Jeffery R. Wilkinson, Bruce W. Horn, Jiujiang Yu, Deepak Bhatnagar and Thomas E. Cleveland. 2007. Genes differentially expressed by Aspergillus flavus strains after loss of aflatoxin production by serial transfers. Journal Applied Microbiology and Biotechnology. Vol 77( 4 )

Coallier., and E. S. Idziak. 1985. Interaction between Streptococcus lactis and Aspergillus flavus on Production of Aflatoxin. Appl. Environ. Microbiol 49: 163 - 167

Eaton, D. L. , and Groopman J. D. 1994. The Toxicology of Aflatoxins. Academic Press, Inc, California. p. $309-312$

Fardiaz, S. 1987. Fisiologi Fermentasi. Pusat Antar Universitas Institut Pertanian Bogor Lembaga sumber Daya Informasi- IPB, Bogor. p.11,15 - 33 .

\section{Mikrobiologi Pengolahan}

Pangan Lanjut. PAU Pangan dan gizi, Bogor. p. 139 - 141, 175 - 182.

1996. Mycotoxin Contamination in Grains - a Review of research in Indonesia. In Mycotoxin Contamination in Grains. Highley, E, \& Johnson, G. I. Australian Centre for International Agricultural research, Canberrra. P. 112 - 119

Grinberg, N. 1990. Modern Thin Layer Chromatography. Marcell Dekker, Inc. New York. p.1- 15, p. 249 - 281.

Haskard, C. A., Nezami, H., Kankanpaa, P. E. Salminen, S \& Ahokas, J. T. 2001. Surface binding of Aflatoxin $B_{1}$ by Lactic Acid Bacteria. Applied and Enviromental microbiology Vol 67 (7) : 3086 - 3091.

Landecker, E. M. 1996. Fundamentals of the Fungi, fourth edition. Prentice Hall, New Jersey. p. $214-220,279-28$ 
Lehninger, 1994. Dasar-Dasar Biokimia. Jilid 2. Terjemahan oleh Maggy thenawidjaya. Erlangga, Jakarta.p. 73 -90

Moat, A. G \& Foster, J. W., 1995. Microbial Phyasiology. Willey- Liss, Inc. New York.

Makfoeld , D. 1993. Mikotoksin Pangan. Penerbit Kanisius, Yogyakarta.

Mehan , V. K., Mc Donald, D, Haravu, L. J. \& Jayanthi, S. 1991. The Groundnut aflatoxin Problem Review and Literature Database. International crops research Institute for the semi Arid Tropics, India. p. 9, 17- 19, 58 -63

Meyers, D.M., Obrian, G., Du, W. L., Bhatnagar, D dan Payne, G.A. 1998. Characterization of aflJ, a Gene Required for Conversion of pathway Intermediates to Aflatoxin. Applied and enviromental Microbiology Vol 64 (10): 3713 - 3717.

Nezami, H, Mykkenen, H., Kankaanpaa, P. E. Salminen, S \& Ahokas, J.T. 2000. Ability of
Lactobacillus and Propionibacterium Strains to Remove aflatoxin $B_{1}$ from the Chicken Duodenum. Journal of Food Protection vol $63(4): 549$ - 552.

Nezami, H. S. \& Ahokas, J.T. 1997. Lactic Acid Bacteria : An Approach for detoxifiction of Aflatoxins. In. Lactic Acid Bacteria : Microbiology and Functional Aspects. Ed. Salminen, S \& Von Wright, A. Marcel Dekker, Inc, New York. p. 359 -366.

Oatley, J. T., M. D. Rarick, G. E. Ji, and J. E. Linz. 2000. Binding of Aflatoxin B1 to Bifido bacteria in vitro. J. Food Prot. 63:11331136.

Ray, 1996. Lactic Acid Bacteria : Current Advances in Metabolism, Genetic, and Application, Springer - Verlag, Germany

Slater, J.H. 1981. Mixed Culture and Microbial Communities. In : Mixed Culture Fermentation. Ed. Bushel, M. E. \& Slater, J. H. Academic Press, London. p. 1-15. 